\title{
An Analysis of Désirée’s Baby from Reader-Response Criticism
}

\author{
Lei Guo ${ }^{1}$, Qianru $\mathrm{Du}^{2 *}$
}

${ }^{1}$ Professor of North China Electric Power University in China

${ }^{2}$ The Post-Graduate Student Majoring in English Language and Literature of North China Electric Power University in China

DOI: $10.36348 / \mathrm{sijl1.2021.v04i01.005}$

| Received: 08.01.2021 | Accepted: 19.01.2021 | Published: 22.01 .2021

*Corresponding author: Qianru Du

\section{Abstract}

In this novel, Kate Chopin vividly described unfortunate suffering and miserable fate of Désirée and her baby with racism as background in the novel, Armand owed the negroid features to Désirée whose origin was obscure even if her skin was whiter than her husband. Kate Chopin unveiled the fact that racism penetrated in the society enormously influencing the mind, action of the individuals living in that environment. Désirée, Armand and the innocent baby were all the victims of the slavery. This work has received considerable attention in that it created suspense by breaking the expectation of the reader. This paper analyze the novel by employing reader-response criticism to Désirée's Baby, from the background of history, the description of environment, the image of characters and the design of ending, so that readers will further experience the pleasure of creation.

Keywords: Désirée's Baby, reader-response theory, gaps, opening ending.

Copyright (C) 2021 The Author(s): This is an open-access article distributed under the terms of the Creative Commons Attribution 4.0 International License (CC BY-NC 4.0) which permits unrestricted use, distribution, and reproduction in any medium for non-commercial use provided the original author and source are credited.

\section{INTRODUCTION}

\section{Historical Context in Désirée's Baby}

Désirée's Baby, which was written by Kate Chopin, was published in her collection A Night in Acadie in 1897 . The story was widely praised due to the exposure of slavery, the Southern social system, and racial identity. The lineage is of great importance in the prewar American South. Family name and status were very critical in southern plantation culture before civil war. Marriages, friendships, and other social relationships would be affected by familial reputations. Désirée's unknown origin was a instrument to the entire plot. Besides, it was the mysterious origin that made Désirée an scapegoat for the scandal of their child's mixed race. The status of land-owning whites, which were placed at the top of social ladder, were superior to the status of black lineage in mid-19th-century Louisiana. To some degree, the author overthrew the whole story by creating unexpected effect. More importantly, she overturned the status of whites that was endowed by American society in which racism and gender discrimination penetrated into the fixed mindset of people. Therefore, the historical context will help readers to grasp the profound meaning of the story.

\section{The Characteristics of Novel}

The most impressive symptom of Kate Chopin's narrative structure is the generic designation of the characters - the yellow nurse, little quadroon boy, Negroes. The absence of proper names, to some degree, indicates that the social or psychological identity is devoid and the cognitive and emotional distance between readers and the text is established. Kate enables the reader to participate in the text and shapes the characters through the circumstance in which they are set. Insignificant expressions and action which have significance to the imagination of the readers. " This is not the baby!" she exclaimed, in startled tones. Madame Valmondé had never removed her eyes from the child. She lifted it and walked with it over to the window that was the lightest. She scanned the baby narrowly, then looked as searchingly at Zandrine, whose face was turned to gaze across the field. The minimal gestures are magnified such as the fixed gaze at the baby, the slight movement of arms, the scanning of the baby, or the observation of the nurse. So all of these would give the readers the impression of being curious in the presence of situation, contributing to readers to predict that there is something wrong with the baby. Judging from the exclamation of Madame Valmonde, readers would be confused by the response of the Désirée who reckoned her mother was astonished by the rapid growth of baby. However, a string of the performances of her mother portrayed by verbs evokes vivid response, readers can sense that there is other reason to explain the action. In order to see clearly of the baby, her mother walked over the window to confirm her judgement. As an experienced woman, realizing that the baby maybe intrigue some unusual things, she turned to Zandrine, the yellow nurse, expecting to see her impression. However, Zandrine 
should turned to gaze across the fields. As a servant of the L'bri, her status was much lower than her master so that she was devoid of the courage to speak her inner thought even if she knew something unusual. Therefore the best way to avoid the embarrassed situation is to gaze at other things.

\section{Readers' Horizon of Expectation}

Reader-response theory received great attention until 1970. He thinks that "the literary has two poles, which we might call the artistic: the artistic refers to the text created by the author, and the esthetic to the realization accomplished by the reader. The work is no more than the text, for the text only takes on life when it is realized, and furthermore the realization is by no means independent of individual disposition of the reader-though this in turn is acted upon by the different patterns of the text" [1]. Wolfgang Iser thinks that the active role of the reader is highlighted in the process of the reading. Reading is an active and creative activity, rather than the passive perception. Additionally, different readers who read the same text will have different understanding. Actually, reader-response theorists maintain that even the same reader who read the same text at different occasions will possibly pick up different perception. Background information and the individual experiences that readers have possessed between our first and second reading, variety in the emotion of the text between reader's two contact with text, or a change of the aim for which reader reads the text can all cause the various meanings. Generally, readers will employ their own specific horizon of expectations before reading or during the process of reading. Aesthetics of reception confirm that readers will feel curiosity and excitement producing unique appreciation of beauty, once the author distance the reader away from the horizon of expectations.

The novel of Désirée's Baby makes fully use of readers' horizon of expectations. The description of environment such as the steep roof, solemn oaks, which exercise a almighty force upon the characters, attracted readers' attention as well, drawing our imagination to the fate of the character. The appearance of the houseusually the novel's dramatic events - are closely related to the fate. When Madame Valmondé reached L'Abri : "she shuddered at the first sight of it, as she always did. The roof came down steep and black like a cowl, reaching out beyond the wide galleries that encircled the yellow stuccoed house. Big, solemn oaks grew close to it, and their thick-leaved, far-reaching branches shadowed it like a pall." The adjective words "shuddered" will be predictor of adversity. The symmetry of the sentences indicate the correspondence between the personality of Armand and the horrified of constructed house. Its syntax gives a indifferent and dehumanized feature to the scene: L'abri is devoid of humane human. On the contrary, the account of the heroine is sensual: "The young mother was recovering slowly, and lay full length, in her soft white muslins and laces, upon a couch. The baby was beside her, upon her arm, where he had fallen asleep, at her breast [2]." More vitality was injected into the house because of the comforted, agreeable atmosphere as well as new-born baby.

The novel begins with a pleasant day, and Madame Valmode drove over to L'Abri to see Désirée and baby. It creates delightful atmosphere for the development of plot. Meanwhile, the title is also an implication of the plot. Readers will conjure up the image of Désirée and baby in their minds. From the description of Madame Valmode, readers can predict that she comes from an affluent family. Additionally, she is an independent woman with merciful heart. Therefore, the title and the first sentence arouse readers' curiosity so that some questions emerge in their mind. Who is the Désirée? What will happen to Désirée and her baby? All of these questions could provide aesthetic expectation for the readers. With the advancement of the reading process, readers realize that Désirée was adopted by Madame Valmode when she was of the toddling age, and the family doted on her. One day when Armand saw her at the gate, he fell in love with Désirée who was gentle and beautiful. "That was the way all the Aubignys fell in love, as if struck by a pistol shot [2]." The scene is ordinary in the eyes of the reader, and the way of falling in love with a girl was common in his family. At the same time, readers would take part in the imagination of the text. If the text presented the whole love story between Armand's mother and father, there was nothing left for readers to imagine. The result of the story will not astonish the readers.

\section{Reconstruction of Expectation}

If a novel always meets readers' horizon of expectation, readers to some extent will feel bored to finish or enjoy the work again. Almost no one reader would like to read the work with expected ending after watching the beginning of the story. The author not only satisfies readers' expectation, but also creates suspense and surprise by using defamiliarzation to break horizon of expectations. The author sets barriers in the establishment of Armand's image. At first, the image of Armand meets readers' horizon of expectation. Then, the author continually creates suspense and misunderstanding for readers by defamiliarization to make the image of Armand presented in the face of readers more variable rather than fixed.

At the beginning of the story, the romantic and devoted image was established in the heart of readers by his words and actions. Armand was attracted by Désirée for her beauty. More importantly, he loved her so much regardless of Désirée's obscure origin showing firm determination when Monsieur Valmondé remanded him that Désirée was nameless. He behaved confidently without caring about others' opinions, and 
he would give Désirée one of the oldest and proudest in Lousiana. Maybe he had prepared everything before marriage. In his family his attitude towards Negroes changed greatly since the birth of the baby. Just as Désirée described: "He hasn't punished one of themnot one of them-since the baby is born. The readers, have been tricked into regarding Armand as a perfect husband because of the superficial performance. The readers couldn't help thinking what leads to the dramatic changes. Maybe it was Désirée and the baby who softened Armand Aubigny's nature which are bossy and stern. However, with the advancement of reading process, readers find that the real image of Armand contrasted unfavorably with previous image which was established in their minds. And last but not least, the reader came to realize that he fell into the trap set by the narrator because he was absorbed in the plot without tolerating anything, When the baby was about three months, unexpected visits from far-off neighbors leads to Armand's strange manner. "When he spoke to her, it was with averted eyes, from which the love-light seemed to have gone out. He absented himself from home; and when there, avoided her absence and that of her child, without excuse [2]." When Désirée realized that the baby was not white, the blood turned like ice in her vein. Readers feel that the color of the baby is likely to cause something unfortunate from the description of her mother who exclaimed in startled tones, and the action of Désirée. When she questioned Armand about the color of the baby, he was cold to her, returning cruelly that the baby was as white as La Blanche's. She was seriously broken by husband's indifference and ultimate answer that Armand wanted her to leave. In silence he ran his cold eyes over the written words. He said nothing. "Shall I go, Armand?" She asked in tones sharp with agonized suspense. "Yes, go." "Do you want me to go?" "Yes. I want you to go." It occurred to readers that they were cheated by previous account after reading these sentences. Their previous expectation was completely overthrown. The frustration of reader's expectations would arouse feelings of vexation. Before marriage, he promised that he didn't mind her origin. Now, he should become cruelly and callous for the baby was not white. How hypocritical he is. The novel is filled with unexpected twists and turns, and frustration of expectations. It is the frustration of expectations that makes readers to modify and reconstruct their horizon of expectations, if not completely change. While these expectations evoke curiosity about what will happen, the subsequent modification of expectations will enable readers to retrospect what they have read.

Finally, the great frustration of expectations was presented on the moral judgement of protagonists, Armand, who abandoned the baby and marriage. In order to avoid his proudest family suffering from unconscious injury because of the color of the baby, Armand compelled Désirée to go through his hardhearted words and actions. When readers considered that the color of the baby was inherited from Désirée whose origin was obscure, few readers would doubt the blood of Armand. After all, he was master who had the proudest and proudest name in Louisiana. However, what made readers astonished was an old letter, which her mother wrote to his father. Here is the content of the letter: "night and day, I thank the good God for having so arranged our lives that our dear Armand will never know that his mother, who adores him, belongs to the race that is cursed with the brand of slavery." The plot frustrates readers again leaving readers to imagine. Readers continually to modify their horizon of expectations in the process of reading, and accomplish the realization of aesthetics.

\section{Appeal Structure: the Indeterminacy of Character and the Gaps in the Text}

The act of creation is not smooth which is associated with the interruptions of the novel. The function of literary text will be better presented by the evocation and negation of the familiar. The thing that we used to think was an affirmation of assumption leading to our negation of them and re-orientation of them. The gaps and indeterminacy in the text indicate readers could actively imagine and reflect in terms of their reading experience and value orientation. In the course of reading, readers will endow the text with more meaning by a series of conscious activities such as logical assumption, analysis and examination.

Iser maintains that there are vacancy and indeterminacy in the meaning. "Expectations aroused in the reader by allusions to the thing he knows or thinks he knows are frustrated; through this negation, we know that the standards and models alluded to are somehow to be transcended. Thus negation can be seen as the inducement to realization - which is the readers' production of the meaning of the text [3]." Therefore, the indeterminacy of literature could evoke readers' imagination to fill the gaps. Iser, the representative of aesthetics of reception, regards the appeal structure as the standard to measure the work, that is to say, the number of indeterminacy was considered as the criterion to judge the value of works. This thesis will analyze the appeal structure demonstrated in Désirée's Baby. Primarily, it is about the obscure origin of Désirée. Monsieur Valmondé found Désirée lying asleep in the shadow of the big stone. There is no doubt that the people in the novel and readers shared different guesses of the Désirée's origin. Who are the natural parents of Désirée's Baby? Why is she left here? Does she get lost? Or is she abandoned by her parents? Does she come from wealthy family? Does she belong to the rank of slavery? However, nothing is provided except the description of her presence. The extent to which the "unwritten" part of the novel arouses readers to participate in the creation of the novel. 
Secondly, it is the identity of Armand's mother who had never been seen in the L'Abri, which is a puzzle to readers. The author mentioned Armand mother with only several sentences. "That was the way all Aubignys fell in love, as if struck by a pistol shot [2]." It was a sad looking place, which for many years had not known the gentle presence of mistress, old Monsieur Aubigny having married and buried his wife in France. Readers would use unwritten implication to predict the identity of Armand's mother and they in turn will influence the written part by endowing the text with greater meaning than that the text might possess. Is his mother beautiful? Is his mother a French? Why does she never appear in the L'Abri? Is she a white woman or slave? At the same time, readers would be greatly attracted to read the story so that they could better testify their predication.

Thirdly, it is the unexpected visits from far-off neighbors. Why does the neighbors visit the baby? Why does an air of mystery spread among the blacks? The unwritten respects of obviously insignificant scenes again stimulate readers imagination to conceive the reason. After reading the whole text, readers find that Armand is the person who really attaches importance to the identity and racism. As he said that he could give Désirée one of the oldest and proudest name. So he really cares about his identity and there is an inherent sense of superiority about his identity. "Young Aubugny's rule was a strict one, too and under it his Negroes had forgotten how to be gay, as they had been during the old master's easy-going, and indulgent lifetime [2]." In the course of reading, readers may wonder why there is great different attitude between the father and the son towards the Negroes. Maybe Armand's father had democratic thoughts which were affected by the democracy because of living in French for so many years. Ultimately, the readers will engage their imagination in the task to figure things out, for reading has become a pleasure for them.

\section{Open Ending of the Novel}

Finally, whether Armand had known the content of the letter written by his mother before he married Désirée was a controversial topic. The novel only referred to the letter exposing his identity at the end of the novel without more information mentioned to indicate whether he had read the letter or not. In order to figure out the answer, readers would look back on the information and reread the whole novel to find evidence for the result. The author once mentioned in the fourth paragraph that: "The wonder was that he had not loved her before; for he had known Désirée since his father brought him home from Paris, a boy of eight, after his mother died there [2]." Readers wound not feel that there is nothing illogical about the sudden love emerging in his heart. However, the careful readers reading the novel several times suddenly realized that the marriage was premeditated by Armand. At the age of eight, he was brought home from Paris after his mother died there. It is likely to say that he had little memory about his mother. According to the content of the letter, readers would again break the possibility that Armand had the memory of his real mother. That is to say, she maybe accompany her son in another identity instead of that of his mother in order to protect Armand from being discriminated by others because of the origin. Some readers predicated that he had read the letter before marriage judging from his attitude towards to Negroes. Some readers held the view that Armand was a calculating hypocrisy who had planned everything before marriage. After reading the letter of his mother, he maybe want to gamble on their marriage. If he was lucky like his parents having a baby with light color like him without evoking great controversy, he would have a happy marriage and be kind to Negroes. If the baby was not white, he could owe the color of the baby to Désirée whose origin was obscure as everyone had known. All of the action showed that he didn't have the courage to admit the reality that his mother was also a slave. Therefore, he burned the letter without leaving any evidence for others and his identity could never be doubted by others. Of course, some readers reckoned that Armand loved Désirée, but he could not bear others' views towards his family. These contradictory cues further demonstrated that Armand is a selfish husband who becomes indifferent to her wife for the color of the baby and the unconscious injury that she brought upon his home and name. Racism to some extent had corroded his mental world contributing to his contorted values that the status and the identity are superior to the life of baby and wife. He didn't see the letter until he dealt with the hangovers belonging to Désirée after the death of her and baby. Otherwise, he would have burnt it earlier when he saw the letter before. So he would feel regret for having done so cruelly for her. Different readers have different explanations about the question, and each explanation have its evidence to account for the reason why Armand did these.

\section{CONCLUSION}

All in all, the meaning rests in the collision between the author and readers. V. N. Voloinov articulated this idea as early as 1930: "there is no reason for saying that meaning belongs to a word as such. In essence, meaning belongs to a word in its position between speakers; meaning is realized only in the process of active, responsive understanding [4]." Kate Chopin focuses on liberating readers' sensibility by employing the connotations which is completely different from stereotypical connotations adopted by conventional narrative codes. She achieves this not only by providing unexpected plot, but also by presenting astonished and exquisite details which enforce readers to experience, at the level of sensation and effect that love affected by social values is transient and unreliable. At the same time, Kate Chopin enables the readers to perceive the ingrained character with shifting 
perspectives and open ending to strengthen the experience of readers.

\section{REFERENCES}

1. Iser, W. (1972). The Reading Process: A Phenomenological Approach [J]. Baltimore: John Hopkins University Press.

2. Chopin, K. (1893). Awaking and Selected Stories of Kate Chopin [M]. New York: New American Library.

3. Iser, W. (1978). The Act of Reading: a Theory of Aesthetic Response [M]. Baltimore: John Hopkins University Press.

4. Voloinov, V. N. (1973). Marxism and the Philosophy of Language [M]. NY and London: Seminar Press. 